\title{
Curriculum Analysis Based on Indonesia's Economic Behavior in The Covid-19 Period
}

\author{
Nanis Hairunisya ${ }^{1, *}$, Sunaryanto $^{2}$ \\ ${ }^{1}$ Study Program of Master in Social Science Education, Universitas Bhineka PGRI, Tulungagung, 66229, Jawa Timur, Indonesia \\ ${ }^{2}$ Faculty of Economics, Universitas Negeri Malang, Malang 65145, Jawa Timur, Indonesia
}

Received August 28, 2020; Revised September 11, 2020; Accepted October 19, 2020

Cite This Paper in the following Citation Styles

(a): [1] Nanis Hairunisya, Sunaryanto , "Curriculum Analysis Based on Indonesia's Economic Behavior in The Covid-19 Period," Universal Journal of Educational Research, Vol. 8, No. 11B, pp. 6351-6360, 2020. DOI: 10.13189/ujer.2020.082274.

(b): Nanis Hairunisya, Sunaryanto , (2020). Curriculum Analysis Based on Indonesia's Economic Behavior in The Covid-19 Period. Universal Journal of Educational Research, 8(11B), 6351-6360. DOI: 10.13189/ujer.2020.082274.

Copyright @2020 by authors, all rights reserved. Authors agree that this article remains permanently open access under the terms of the Creative Commons Attribution License 4.0 International License

\begin{abstract}
The implementation of the economics curriculum 2013 still faces various obstacles and not all educators understand that Indonesian economic values must be taught in schools. Meanwhile, the need for student behavior based on Indonesian economic values is increasingly urgent. The purpose of this study is to examine the curriculum based on Article 33 of the 1945 Constitution during the Covid 19 period, as a basis for making teaching materials. This study uses qualitative methods and focus group discussion as a means of validating data following observation, documentation and interviews. What is analyzed is the general objectives of the curriculum and philosophy of economics. It is found that the philosophy of Indonesian economic behavior has not been accommodated in the curriculum material. The systematics of matter is incompatible with the systematics of economic theory. There is no philosophical foundation of essentialism and philosophy for solving social problems. Economic theory learning is integrated with applied economics. The formulation of the basic competencies of the curriculum does not actualize changes in the economic life of the community during the Covid 19 period. It was found that there was a shift in the values and culture of society in solving economic problems and the implementation of the quality of learning was indicated to have decreased, because teachers and students had to change their face-to-face learning behavior with online learning. The reconstruction of the economic education curriculum in SMA should be carried out. Contribution in the field, there needs to be a reconstruction of the economic education curriculum, especially in the material structure, determination of basic competencies based on Indonesian economic behavior that uses a humanist approach, experimentalism and social reconstructivism in anticipating shifts in the values and culture of society in solving economic problems.
\end{abstract}

Keywords Curriculum Analysis, Indonesian Economic Behavior, Covid-19

\section{Introduction}

Various studies [1,2,3], the quality of learning and economic education is still low, therefore it needs to be improved. [4] The importance of improving the quality of economic education is closely related to the demands for the formation of economic behavior in anticipation of change $[5,6]$ based on Indonesian economic values [7] which are legally formally stated in the 1945 Constitution [8], especially during the covid 19 pandemic.

Based on the results of the interaction regarding the implementation of the 2013 Curriculum (K13) with high school economics teachers before and during the Covid 19 pandemic, $[9,10,11]$ it was found that teachers lacked mastery of economic material, the concepts taught were not correct and did not know economic value based on the 1945 Constitution (UUD 1945) the nation's ideology is important. Several research results on the contradiction of readiness and unpreparedness for implementing the 2013 curriculum were found by $[12,13][14]$ who found the unpreparedness of the learning tools to implement the 2013 curriculum. In contrast to [15] found that economic teacher preparation was classified as good which was supported [16].

The main problem the teachers facing in implementing economics teaching is the preparation of Thematic Integrated Learning Implementation Plans (RPP) and the lack of teacher 
handbooks [17]. In addition there are (1) lack of learning facilities and infrastructure; (2) students have difficulty understanding the material and examples of questions in textbooks; (3) Lack of teacher's ability to use science and technology $[18,19]$. Another difficulty is that teachers do not fully understand the assessment system, develop attitude instruments, apply authentic assessments, formulate indicators, design assessment rubrics for skills, and collect scores from a variety of measurement techniques and cannot find suitable applications to describe student achievement. [20] This condition results in students having difficulty understanding economics, not being interested in studying it and feeling bored. Students do not understand the economic values that refer to the mandate of the 1945 Constitution and Pancasila, which should underlie economic systems and practices in Indonesia. [21]

Based on the constraints facing the teachers in implementing the 2013 curriculum in the period before Covid 13, the research question was how the 2013 curriculum was implemented during the Covid period if it was guided by the economic behavior of the Indonesian people listed in the 1945 Constitution.

The originator of curriculum development was Ralph W. Tyler. Tyler's ideas became the Basic Principles of the Curriculum and became a standard reference for curriculum development. Curriculum planning is an ongoing cycle process, an educational instrument that needs to be adjusted. Tyler stated that the curriculum is a powerful and effective tool for educators who integrate national goals with students' needs [22].

The aim of school curriculum 2013 (K13) is to prepare students to be pious, productive, innovative, creative and affective and can play a role in society, nation, state and world culture. The character values implemented in the curriculum 2013 were developed in students through two attitudes namely spiritual aspects and social aspect [23], by making observations, asking questions and reasoning about the knowledge being taught. [24] taught [25]. There is integration between subjects and levels of education. as well as the affective, cognitive and psychomotor [aspect [26]. Students can freely choose their development interests, the division of subject groups based on cognitive, affective, and psychomotor aspects, as well as the absence of a ranking system, the absence of English lessons for elementary school level and the absence of ICT lessons at all levels [27].

This curriculum 2013 were improved in 2017 and 2018. Matters related to changes in curriculum 2013 revised in 2018: (1) permanent curriculum name; (2) core competencies is only written in lesson plan; (3) only the highest value is taken if there are 2 values in 1 basic competency, both daily and the end of the semester assessment have the same weight for knowledge aspect; (4) it is possible to use an approach other than scientific in teaching; (5) the syllabus is short; (6) daily exams become daily assessments, end of semester exams become end of semester assessment and end of year assessment in first and second semester, and there are no midterm exams; (7) learning methods is not included in the lesson plan, and the teaching material and assessment rubric are written as an appendix; (8) range of values is 1 to 100 and attitude assessment are in the form of predicate and description; (9) students are given additional learning if they are less able then to be retested and given a repeat test score. (10) All teacher administration in the 2018/2019 school year has been provided online [28]. In order to implement the K13 strategy to achieve high quality, documents and instruments are very important foundations [29].

Pancasila and the 1945 Constitution constitute the philosophy of life of the Indonesian Nation and the legal basis for regulating the life of the Indonesian Nation, including in education and economics. Indonesian economic policy should be guided by the articles and paragraphs in the 1945 Constitution. Ideas, concepts and theories about economic management based on the values of the 1945 Constitution that's the Indonesian economy [30,31]. It can be stated that the Pancasila and the 1945 Constitution are guidelines for the Conduct of the Indonesian Nation.

The unification of meaning about Pancasila and the development of Indonesia's national education is the urgency of nationalism in building the nation. The urgency of Pancasila as the philosophical basis of the state is the basis of the philosophy of Indonesia's national education and the urgency of national education in building personality (character of the Indonesian Nation) [32]. In this regard, the Indonesian economy is often also expressed as a people's economy. Article 23 paragraph 1, article 27 paragraph 2, and article 34 paragraph 1 of Chapter X of 1945 Constitution explicitly have relationship with economic field, and are considered worthy to be examined in exploring the meaning of Indonesia economic.

Articles and paragraphs in the 1945 Constitution as explained above, in principle are the formal legal basis for the Indonesia economic system which is often referred to as economic democracy or people's economy.

\section{Materials and Methods}

This research is a qualitative research. Most of the data is collected by analyzing documents. To maintain the credibility of the data, researchers took key informants from high school teachers who had more than 10 years of service as representatives of curriculum schools in 3 high school schools. The sampling was based on a recommendation from the Economics Subject Teachers Group, which consisted of 29 economics teachers. Data credibility is also intentionally maintained by the involvement of researchers and informants in several joint activities such as student teaching practicums and several educational seminars. To maintain the validity of the data, the researchers conducted member checks by re-evaluating the data to the informants after data analysis [33]. In addition, a focus group discussion (FGD) was conducted $[34,35]$ with a participatory team to get contextual understanding of various aspects related to the curriculum.

The documentation and questionnaire techniques are used to find data on teacher opinions about the importance of economic education based on Indonesian economic behavior in implementing learning. Interview techniques are also used to explore and complete the data collected. Data analysis was performed by categorizing, classifying and drawing conclusions [36]. Data collection instruments in this study is shown in table 1 . 
Table 1. Aspects Of Curriculum Assessment and Criteria

\begin{tabular}{|c|c|c|c|c|c|c|}
\hline \multirow{2}{*}{ No } & \multirow{2}{*}{ Aspect } & \multicolumn{2}{|c|}{ Idealcompetence* } & \multicolumn{3}{|c|}{ Material** $^{*}$} \\
\hline & & \begin{tabular}{l|l}
1 & 2
\end{tabular} & 3 & 1 & 2 & 3 \\
\hline 1 & General purpose subjects & & & & & \\
\hline 2 & Core competency & & & & & \\
\hline 3 & Basic competencies & & & & & \\
\hline
\end{tabular}

*1 competence of national-minded economic behavior, 2. rational economic behavioral competence, 3. altruistic economic behavioral competencies **1. the meaning of economic discipline, 2. systematic scientific economics, 3. presentation sequence/discussion

\section{Finding}

\subsection{The results of the 2013 Economic Education Cur- riculum study in high school.}

Manuscripts of 2013 Curriculum and revised editions reviewed for evaluation are obtained from a copy of Minister of Education Regulation. According to the regulation, general rational obtained from the curriculum 2013 development as follow.

This curriculum change is made to strive for the abundant productive age human resources which will reach its peak in $2020-2035$ by 70

This study found that the thought patterns that were considered inappropriate so far in the implementation of education were mostly not objective and influenced by the political situation.

This study found that the mindset that had been considered inappropriate in the delivery of education was largely not objective and influenced by the political situation.

The results of research on strengthening curriculum governance related to teacher work procedures, strengthening school management and learning process infrastructure state that what has been achieved previously is good. The aspects that are strengthened have little effect on the curriculum, because of the autonomy given to schools. developing and managing curriculum is more urgent to implement.

The results of the study found that there was no expansion and deepening of the material and the increase in relevance to the needs of students. this is due to the development of the material, shackled by the core competencies that are common to all subjects.

The idea of the 2013 curriculum characteristics is very good, but these well-formulated characters are in fact not realized in the development of core competencies (CC) and Basic Competencies (BC) which become a reference for teachers to design learning and evaluate learning outcomess.

The basic philosophical formulation is explained very clearly in the curriculum framework, which states that national culture is the root of education and those who will inherit the culture are students. Philosophical foundations related to national culture should be applied to all subjects that are directly related to the formation of student behavior characterized by Indonesianism.

Judging from its purpose, it is written "preparing Indonesian people" and so on until the word "and affective". The word "affective" does not indicate adjectives regarding human conditions but has a general meaning related to feelings of fear, hate, revenge, love and so on. the word is better to be replaced by "upholding the nation's culture." Because in the global era and world competition the development of Indonesian people with a strong national character is absolutely necessary. The questionnaire results regarding curriculum assessment will be presented as following.

Data on the results of the 2013 curriculum assessment economic subjects in high school is shown in table 2.

The philosophical foundation based on Indonesian economic behavior is not stated explicitly in the basic competencies (BC) of economic subjects. The juridical foundation of basic competence (BC) tends to be capitalist and liberal based.

The composition of core competencies (CC) in the 2013 curriculum is made the same for all subjects with the assumption of maintaining integrity for various basic competencies (BC), even the formulas for each class are made similar and in no order relevant to the stages of student growth and development. For more details, below is core competence statements which covers all competencies for all grade levels. For more details, table 3 is core competence statements which covers all competencies for all grade levels.

The 1st and 2nd Core Competencies which address spiritual and social attitudes are made the same for the tenth, eleventh and twelfth grades. Whereas the third and fourth Core Competencies, the difference in formulation is only indicated by the words that are italicized and in bold.

It is clear that the arrangement of $\mathrm{CC}$ which is used to vertically integrate of $\mathrm{CC}$ word order cannot fulfill the objective, because the competency gradations between class levels are not formulated explicitly in the $\mathrm{CC}$ for each level. Table 4 contains data about IC in the first row, followed by BC in the next row, for economic subjects.

The formulation of core competencies (CC) has shackled the description of $\mathrm{BC}$ and resulted in $\mathrm{BC}$ not being operational to be used as a reference in developing teaching and learning activities. Especially BC which is explained from point one CC, namely religious attitudes and $\mathrm{CC}$ point two, namely social attitudes.

The separation of IC for knowledge and skills in principle was correct because the curriculum developed was based on competence. However, when translated in the BC statement, the formula it becomes illogical due to the lack of understanding of what competencies are included in the realm of knowledge and what competencies are included in the realm of skills.

For example BC 2 on CC knowledge in class XII reads: "Analyzing international economic cooperation" KD's formula for its skills reads: "Presenting the results of an analysis of international economic cooperation". Analyzing interpreted as knowledge competence and presents interpreted as skills. It is proven that the framers of $\mathrm{BC}$ lack understanding of the difference between knowledge and skill competencies. In subjects 
Table 2. Data of 2013 curriculum assessment results

\begin{tabular}{|c|c|c|c|c|c|c|c|}
\hline \multirow{2}{*}{ No } & \multirow{2}{*}{ Aspect } & \multicolumn{3}{|c|}{ Idealcompetence* } & \multicolumn{3}{|c|}{ Material** } \\
\cline { 3 - 8 } & & $\mathbf{1}$ & $\mathbf{2}$ & $\mathbf{3}$ & $\mathbf{1}$ & $\mathbf{2}$ & $\mathbf{3}$ \\
\hline 1 & General purpose subjects & NA & NA & NA & NA & NA & NA \\
2 & Core competency & E & L & E & VL & VL & VL \\
3 & Basic competencies & L & E & VL & L & VL & VL \\
\hline \multicolumn{8}{r}{ Information : }
\end{tabular}

NA ; Not Available, E: enough, L; less, VL; very less

Table 3. Core Competencies of High School / Madrasah Aliyah

\begin{tabular}{|c|c|c|}
\hline Class X & Class XI & Class XII \\
\hline $\begin{array}{l}\text { Appreciate and practice the teachings of the reli- } \\
\text { gion they hold }\end{array}$ & $\begin{array}{l}\text { Appreciate and practice the teachings of the reli- } \\
\text { gion they hold }\end{array}$ & $\begin{array}{l}\text { Appreciate and practice the teachings of the reli- } \\
\text { gion they hold }\end{array}$ \\
\hline $\begin{array}{l}\text { Appreciate and practice honest behavior, disci- } \\
\text { pline, responsibility, care (mutual cooperation, } \\
\text { cooperation, tolerant, peace), polite, responsive } \\
\text { and pro-active and show attitude as part from so- } \\
\text { lutions to various problems in interacting effec- } \\
\text { tively with the social and natural environment and } \\
\text { in placing oneself as a reflection of the nation in } \\
\text { the world association }\end{array}$ & $\begin{array}{l}\text { Appreciate and practice honest behavior, disci- } \\
\text { pline, responsibility, care (mutual cooperation, } \\
\text { cooperation, tolerant, peace), polite, responsive } \\
\text { and pro-active and show attitude as part from so- } \\
\text { lutions to various problems in interacting effec- } \\
\text { tively with the social and natural environment and } \\
\text { in placing oneself as a reflection of the nation in } \\
\text { the world association }\end{array}$ & $\begin{array}{l}\text { Appreciate and practice honest behavior, disci- } \\
\text { pline, responsibility, care (mutual cooperation, } \\
\text { cooperation, tolerant, peace), polite, responsive } \\
\text { and pro-active and show attitude as part from so- } \\
\text { lutions to various problems in interacting effec- } \\
\text { tively with the social and natural environment and } \\
\text { in placing oneself as a reflection of the nation in } \\
\text { the world association }\end{array}$ \\
\hline $\begin{array}{l}\text { Understanding, applying, analyzing factual } \\
\text { knowledge, conceptual, procedural based on } \\
\text { curiosity about science, technology, art, culture, } \\
\text { and humanities with the insight of humanity, } \\
\text { nationality, statehood and civilization related to } \\
\text { the causes of phenomena and events, as well } \\
\text { as applying knowledge procedures in a specific } \\
\text { field of study in accordance with their talents and } \\
\text { interests to solve problems }\end{array}$ & $\begin{array}{l}\text { Understand, apply and analyze factual knowl- } \\
\text { edge, conceptual, procedural and metacognitive } \\
\text { based on curiosity about science, technology, art, } \\
\text { culture, and humanities with the insight of hu- } \\
\text { manity, nationality, statehood and civilization re- } \\
\text { lated to the causes of phenomena and events, as } \\
\text { well as applying knowledge procedures in a spe- } \\
\text { cific field of study in accordance with their talents } \\
\text { and interests to solve problems }\end{array}$ & $\begin{array}{l}\text { Understand, apply analyze and evaluate factual, } \\
\text { conceptual, procedural and metacognitive knowl- } \\
\text { edge based on curiosity about science, technol- } \\
\text { ogy, art, culture, and humanities with human, na- } \\
\text { tionality, state, and civilization insights related to } \\
\text { the causes of phenomena and events, and apply } \\
\text { knowledge procedures in a specific field of study } \\
\text { in accordance with their talents and interests to } \\
\text { solve problems }\end{array}$ \\
\hline $\begin{array}{l}\text { Cultivate, reason, and serve in the realm of con- } \\
\text { crete and abstract domains related to the develop- } \\
\text { ment of what is learned at school independently, } \\
\text { and able to use methods according to scientific } \\
\text { principles }\end{array}$ & $\begin{array}{l}\text { Cultivate, reason, and serve in the realm of con- } \\
\text { crete and abstract domains related to the develop- } \\
\text { ment of what is learned in schools independently } \\
\text { acting effectively and creatively and are able to } \\
\text { use methods according to scientific principles }\end{array}$ & $\begin{array}{l}\text { Cultivate, reason, and serve in the realm of con- } \\
\text { crete and abstract domains related to the develop- } \\
\text { ment of what is learned at school independently } \\
\text { and act effectively and creatively and able to use } \\
\text { methods according to scientific principles }\end{array}$ \\
\hline
\end{tabular}

Source: Permendikbud Copy Number 69 of 2013

whose substance is more theoretical in nature, the meaning of skill competence should be interpreted not as physical skills, but rather thinking skills in a high domain, such as analyzing, synthesizing and evaluating.

In terms of material content, both in terms of the systematic presentation and scope, the weaknesses are also seen. The contents of the material referring to the KD in the 2013 Curriculum can be tabulated in table 5 .

The systematics and sequence of economic subjects in the 2013 curriculum are not the same as the systematics of economic material based on theoretical study rules. Based on generally accepted theoretical principles, after the basic concepts of economics will be followed by consumer and producer behavior, demand and supply theory, which will be followed by material on the interaction of demand and supply in the market. The discussion on consumer and producer behavior only focuses on the roles of consumers and producers, while the theory of supply and demand is not discussed.

In general, after market material and the formation of market prices, it will be discussed about maximizing profits in various forms of the market. But in the 2013 curriculum, the discussion of microeconomic material stops only until the formation of market prices. However, after the material was immediately followed up on financial institutions, payment systems and instruments as well as management concepts. Based on this se- quence, it is clear that the 2013 curriculum does not consider systematics based on economic scientific principles and rationality.

The last discussion in the tenth grade, after completing the management material, students studied the subject of cooperatives. Meanwhile, in the eleventh class, they were given material on macro economics. The discussion begins with economic development and continues with employment. After that, material related to macroeconomic topics, namely national income, APBN and APBD, roles, functions and benefits of taxes are discussed, followed by a discussion of inflation and economic policies. Meanwhile, macroeconomic actors, which should have been discussed before taxation, were only discussed after the topic of economic policy.

This caused the discussion of the macroeconomic sequence to be disrupted, it should have been after the discussion of national income that the circular flow diagram was discussed, it should be continued with macroeconomic actors, and demand and aggregate supply continued with the combined macroeconomic balance of the money market and the goods market. Eleventh grade students, at the end of the session must study the capital market, material that is not related to the previous discussion.

The systematics of the twelfth grade economic learning materials is more concerning. At the beginning of entering the 
class, students study international economic material with the topic of concepts and policies on international trade and international economic cooperation. This incomplete material on international economics is terminated with material that is not at all related to economic theory, namely accounting material.

The order of the material which does not conform to the rules of this theory is also contrary to the formal education tracking system in Indonesia, where the single track system is adopted at the primary education level, while the secondary education level adopts a multi-track system. There is a general education pathway and there is a vocational education pathway. So that the insertion of accounting material after international economics is not relevant to the formal education system in Indonesia.

As is known, the general education pathway directs its graduates to continue to higher education with general majors such as universities. Meanwhile, the vocational education pathway directs graduates to be ready to work or pursue higher education with vocational specifications such as institutes or polytechnics.

Including accounting and management material in economics education in high school, proves that the compilers of curriculum materials do not understand that SMA is a formal middle-level general education whose graduates will continue to university. For a major or specialization in a vocational high school for economics, there is a vocational high school for business and management, formerly known as the Senior High School for Economics (SMEA), with accounting, office and marketing specifications.

Economics education at the high school level should focus on theoretical economics, not applied economics such as accounting and management. Both of these topics should be replaced with topics of economic theory, to cover economic topics that have not been covered, as previously stated.

\section{Discussion}

The importance of education for Indonesia's economic growth, requires the Indonesian people to continue to improve the quality of teaching and learning so that future generations of people who are still learning can understand economics and are expected to improve Indonesia's economy in the future, despite the current covit 19 pandemic which will reduce Indonesian economic growth. As word bank reports about the Ebola epidemic in Africa [37-40]

Based on the results of the study, it is known that the philosophy in the 1945 Constitution has not been fully accommodated in the 2013 Curriculum, in line with $[41,42]$ finding a changing direction of economic policy.

It is proven that the formulation of $\mathrm{KD}$ in the curriculum does not pay attention to the changes that occur in the people's economy, especially during this covit 19 period. The importance of this KD formulation referring to changes in the people's economy is that students are accustomed to caring about and expected economic behavior of students in the future according to the 1945 Constitution. In addition, students will be trained to be ready to face challenges in solving problems of poverty and unemployment. Especially during the Covid 19 pandemic, there was a shift in the values and culture of society globally in solving economic problems. As stated by several studies on the impact of Covid 19 on the education and economic sectors [43 - 47].

The systematics and sequences of economic subject matter in the 2013 Curriculum do not reflect the systematic discussion of economic material that generally applies in economic theory studies. The above weaknesses have a more pronounced impact on educators at the time of Covid 19, when the habits, behavior of students and teachers change with online learning.

The material contained in K13, clearly and expressly has no content related to the norms contained in the chapter in question. For example, the values in Article 27 paragraph 2 are only related to the material content concerning labor issues in Indonesia. [48] found that the important role of the state in allocating economic resources for common prosperity and welfare, extra attention to the duafa and neglected children through economic policy instruments and the curriculum is part of one of the state policy instruments.

Economic education should arouse students' enthusiasm for the importance of fulfilling the rights and obligations of citizens as mandated by the 1945 Constitution, that every citizen has the right to a decent job and livelihood. It is hoped that this cultivation of values and culture in the future can contribute to society in carrying out the mandate of the law. Meanwhile [49] predicts that by 2030 the behavior of young people will be more rational, analytical, linear, individual, and secular.

Apart from that related to the problems of social welfare and the Indonesian economy according to the 1945 Constitution, it is time to develop an economic education curriculum using humanism, experimentalism and social reconstructivism approaches. The use of the aforementioned approach is in order to humanize humans, uplifting the dignity of the Indonesian nation both individually and in groups [50].

In the appendix [51] which describes the philosophical foundation of the curriculum which aims to build contemplative abilities in solving social problems in society and to better shape democratic community activities. not reflected in the structure of the economic curriculum underpinning this philosophy.

In another part of the annex to the Permendikbud, it is stated that the philosophy of essentialism, which requires that the curriculum has a subject name (subject) is no different from scientific disciplines with the intention of exposing intelligence skills and academic success. In fact, the essentialism philosophy which is used as the basis for the development of the 2013 curriculum is limited to subject titles without interpreting scientific disciplines. This is because the requirements for the development of curriculum materials must be based on a relevant scientific theoretical framework, comprehensive concepts, scientific principles and material systematics that apply to these disciplines. This requirement cannot be fulfilled by the 2013 economic curriculum. The concepts, rules and procedures in economics are presented in fragments and are not comprehensive, and the systematization is not in accordance with economic science. The study of economic theory is mixed with applied economics in the form of material content on manage- 
ment, cooperatives and accounting.

This is completely different from the economic curriculum applied in various countries such as Finland, Singapore, Hong Kong, Australia and the United States. Not to imitate other countries, but rather to compare and draw on experiences from the countries in question. It is proven in these countries that economic education has been able to contribute in shaping the economic behavior of the people according to their economic philosophy [52,53]. Based on the description above, it is appropriate to reconstruct the economic education curriculum in SMA based on the economic behavior of the Indonesian nation as stipulated in the 1945 Constitution.

Reconstruction of the economic education curriculum can be done by overhauling the structure of the 2013 curriculum, in the following ways: (a.) Reformulating Basic Competencies (KD) which are translated from KI two to KI four den

\section{Conclusion}

The foundations for the Indonesian nation's economic behavior contained in the 1945 Constitution are not entirely included in the 2013 economic curriculum. There is no material that clearly contains the substance of article twenty-seven paragraphs two, thirty-three and thirty-four of the 1945 Constitution.

In the 2013 economic curriculum, the curriculum development requirements are not fulfilled. The essentialism philosophy that is used as the basis for improving the 2013 curriculum is limited to subject titles but not in accordance with scientific disciplines. In addition to being given a title according to scientific characteristics, the content of the material in the curriculum for improvement must meet the rules based on the relevant scientific theory building, including the comprehensiveness of the concepts and scientific and systematic principles applicable to the discipline of economics. The study of economic theory is mixed with applied economics. This study concludes that the objectives of economic education in SMA cannot be maximally achieved if the curriculum has not been improved

Based on the findings above, which contain some weaknesses and strengths of the revised 2013 curriculum, educators and education-related institutions can map the needs and what improvements can be made to improve them in order to improve the quality of education. This is very much needed, especially when we are currently in the Covid 19 pandemic. During the Covid 19 period, the implementation of the quality of learning was indicated to have decreased, because of the many changes in habits and learning behavior online. The weaknesses of the findings above will be more pronounced when learning habits and behaviors also change from face-to-face to online learning.

Some changes that should be made and can be taken into consideration for the development of learning enrichment books for teachers, student handbooks and student worksheets based on Indonesian economics online.

\section{Acknowledgements}

Thank you to the beloved campus STKIP PGRI Tulungagung which has now been transformed into the Bhinneka University PGRI Tulungagung. Thank you also conveyed to Malang State University as a partner institution in research. Besides that, thank you to Mr. and Mrs. Teachers who provided information related to the curriculum.

\section{REFERENCES}

[1] Sullivan, T. A., Mackie, C., Massy, W. F., and Sinha, E. Improving measurement of productivity in higher education. Improving Measurement of Productivity in Higher Education. Publisher: National Academies Press, United State of America, 2013

[2] Aleandri, G., and Refrigeri, L, Lifelong Learning, Training and Education in Globalized Economic Systems: Analysis and Perspectives. Published by Elsevier Ltd. Procedia - Social and Behavioral Sciences. Vol.93, p.p: 1242-1248, 2013

[3] Hrynkevych, O. S., and Lutchyn, N. P. Analysis and modeling of processes of internationalization in higher education in the context of innovative development, Department of Marketing and Management of Innovative Activity of Sumy State University, Journal Marketing and Management of Innovations. No. 3, 314-325, 2017.

[4] Papageorge, N. W., Ronda, V., and Zheng, Y, The Economic Value of Breaking Bad Misbehavior, Schooling and the Labor Market. Online available from http://www.nber.org/papers/w25602.pdf.

[5] Hanushek, E. A. . The economic value of higher teacher quality. Published by Elsevier Ltd. Journal Economics of EducationReview. Vol.30 No. 3 Pp 466-479, 2011.

[6] Sánchez, A. R. P., García, M. J., and Chico, J. R.. Human capital, investment on education and economic growth: A review and updating of regional economic asymmetry in Spain (19802012). Universidades De Andalucia, Journal Revista de Estudios Regionales, Vol. 106, pp. 21 -53, 2016

[7] Hairunisya, N. Analysis of Lesson Plan, Learning Process, Teacher Competence Based on The Indonesian Economics. Department of Economics Education, Faculty of Economics, Universitas Negeri Semarang, Dinamika Pendidikan.Vo. 13. No. 1. Pp. $54-71.2018$

[8] Undang-undang Dasar RI Tahun 1945 (UUD 1945) Online available from http://www.dpr.go.id/jdih/uu1945.

[9] Mustofa, Upaya Pengembangan Profesionalisme Guru di Indonesia. Jurusan Pendidikan Ekonomi Fakultas Ekonomi Universitas Negeri Jogjakarta, Jurnal Ekonomi Dan Pendidikan. Vol.4, No. 1, p.76-88. 2007.

[10] Sopiyana, M., and Sugiyono, S. Efektivitas Kinerja Musyawarah Guru Mata Pelajaran (Mgmp) Ekonomi SMA Di Kabupaten Boyolali. Publisher Graduate School, Universitas Negeri Yogyakarta, Jurnal Akuntabilitas Manajemen Pendidikan. Vol.3, No.2 p. 241-249, 2015 
[11] Sriyanto, S., Murniawaty, I., Nuryana, I., and Ismiyati, I. Peningkatan Profesionalisme Guru Ekonomi dalam Pembelajaran di SMA Kabupaten Semarang. Publisher: Lembaga Publikasi Ilmiah dan Penerbitan Universitas Muhammadyah Purwokerto, JPPM (Jurnal Pengabdian Dan Pemberdayaan Masyarakat). Vol.2, No.2, p. 357-362, 2018

[12] Rindrayani, S. R. The Implementation Of Character Education in Indonesia High School Curriculum Program. Horizon Research Publishing(HRPUB), Universal Journal of Educational Research. Vol.8. No.1. p. 304-312, 2020

[13] Palobo, M., and Tembang, Y. Difficulty Of Teacher In Implemeting Thematic Learning In Basic Schools In Merauke Papua. Granthaalayah Publications and Printers International Journal of Research -Granthaalayah. Vol.7, No.11. p. 85-95, 2020

[14] Rumahlatu, D., Huliselan, E. K., and Takaria, J. An Analysis Of The Readiness And Implementation Of 2013 Curriculum In The West Part Of Seram District, Maluku Province, Indonesia. Veritas Publications LTD, UK International Journal of Environmental and Science Education. Vol. 11, No,12. P. 5662-5675, 2016

[15] Muslimin, and Destriana. Evaluation Of Curriculum Implementation Of 13 Sports And Health Education Teachers. Horizon Research Publishing (HRPUB), Universal Journal of Educational Research, Vol. 8, No. 1, p. 27-35. 2020

[16] Budiani, S., Sudarmin.S., Syamwil, R.. Evaluasi Implementasi Kurikulum 2013 di Sekolah Pelaksana Mandiri. Pengembang Kurikulum, Pasca Sarjana UNNES, Innovative Journal of Curriculum and Educational Technology, Vo. 6, No. 1. p. 45-57. 2017

[17] Hindrasti, N. E. K., Putri, A. N., and Muhartati, E. , Peningkatan Kemampuan Guru dalam Menyusun RPP Terintegrasi Adiwiyata Berbasis Isu-isu Kritis Lokal pada Calon Sekolah Adiwiyata di Tanjungpinang. International, Universitas Pendidikan Ganesha, Journal of Community Service Learning. Vol. 3. No. 3. p. $158-166,2019$

[18] Retnawati, H., Hadi, S., and Nugraha, A. C., Vocational high school teachers' difficulties in implementing the assessment in curriculum 2013 in Yogyakarta Province of Indonesia. Eskisehir Osmangazi University Faculty of Education International Journal of Instruction. Vol. 9, No. 1, p.33-48, , 2016

[19] Retnawati, H., Munadi, S., Arlinwibowo, J., Wulandari, N. F., and Sulistyaningsih, E. Teachers' difficulties in implementing thematic teaching and learning in elementary schools. Adam Marszałek Publishing House, New Educational Review. Vol. 48, p. 201- 212, 2017.

[20] Darsih, E., Indonesian Efl Teachers' Perception On The Implementation Of 2013 English Curriculum. Publisher: Department of English Education, Faculty of Teacher Training and Education, the University of Kuningan (PBI FKIP UNIKU) in collaboration with the Association of Indonesian Scholars of English Education (AISEE), English Review: Journal of English Education.Vol.2, No.2, p. 1-8, 2014

[21] M. Witjaksono. Analisis Kritis dan Pragmatis Caring Economics sebagai Paradigma baru Kajian Ekonomi., Publisher Fakultas Ekonomi Universitas Negeri Malang, Jurnal Ekonomi dan Studi Pembangunan, Vol.8, No. 2, 2016
[22] Tyler, R. W., Basic Principles of Curriculum and Instruction. Basic Principles of Curriculum and Instruction. University of Chicago Press, United States of America, 2013

[23] Kemendikbud RI, Modul Pelatihan Implementasi Kurikulum 2013. Badan Pengembangan Sumber Daya Manusia Pendidikan dan Kebudayaan dan Penjaminan Mutu Pendidikan, Kementerian Pendidikan dan Kebudayaan. Indonesia, 2013

[24] Muassomah, Abdullah, I., Istiadah, Mujahidin, A., Masnawi, ,Indonesia's Youth. Horizon Research Publishing (HRPUB), Universal Journal of Educational Research, Vol. 8, No. 6 , p. 2223-2231. 2020

[25] Friska Fitriani Sholekah. Pendidikan Karakter Dalam Kurikulum 2013. LP2M Intitut Agama Islam Al-Qodiri Jember Childhood Education: Jurnal Pendidikan Anak Usia Dini. Vol. 1, No. 1, p. $1-6,2020$

[26] Kemdikbud. Peraturan Menteri Pendidikan dan Kebudayaan No 24 Tahun 2016 Tentang Komptensi Inti dan Kompetensi Dasar. Kementerian Pendidikan dan Kebudayaan, Indonesia, 2016

[27] Kemdikbud, Peraturan Menteri Pendidikan Dan Kebudayaan Republik Indonesia Nomor 12. Tahun 2018 Tentang Perubahan Atas Peraturan Menteri Pendidikan Dan Kebudayaan Nomor 22 Tahun 2015 Tentang Rencana Strategis Kementerian Pendidikan Dan Kebudayaan Tahun 2015-2019, Kementerian Pendidikan dan Kebudayaan, Indonesia, 2018

[28] Katuuk, D. A. Manajemen Implementasi Kurikulum: Strategi Penguatan Implementasi Kurikulum 2013. Institute of Educational Development and Quality Assurance of Yogyakarta State University (LPPMP - UNY), Jurnal Cakrawala Pendidikan. Vol. XXXIII, No. 1, p. 13-26 2014

[29] M. Witjaksono. Redefinisi, Reorientasi, dan Redesain Pembelajaran Ekonomi mengacu pada Amandemen pasal 33 UUD 1945. Publisher: Fakultas Ekonomi, Universitas Negeri Malang, Jurnal Pendidikan Ekonomi, Vol. 6, No. 1. p. 1-12, 2013

[30] Siswoyo, D. Pandangan Bung Karno Tentang Pancasila Dan Pendidikan. Institute of Educational Development and Quality Assurance of Yogyakarta State University (LPPMP - UNY), Jurnal Cakrawala Pendidikan. Vol. XXXII, Vol. 1, p.103-115, 2013

[31] Alfian, Feith, H., and Castles, L., Indonesian Political Thinking: A Review,. Published by Cornell University Press, Indonesia Journal, No. 11, pp. 193-200, 1971

[32] Van Der Kroef, J., Feith, H., Castles, L., and Tregonning, K. Indonesian Political Thinking, 1945-1965. Published by: Pacific Affairs, University of British Colombia, Pacific Affairs. Vol. 43, No. 4, pp. 638-639, 1971

[33] Birt, L., Scott, S., Cavers, D., Campbell, C., and Walter, F., Member Checking: A Tool to Enhance Trustworthiness or Merely a Nod to Validation? SAGE Journals, Qualitative Health Research. Vol. 26, No. 13, p.1802-1811, 2016

[34] Stewart, D., Shamdasani, P., and Rook, D. Analyzing Focus Group Data. In Focus Groups. SAGE Publishing, United States of America, 2012 
[35] O.Nyumba, T., Wilson, K., Derrick, C. J., and Mukherjee, N. The Use Of Focus Group Discussion Methodology: Insights From Two Decades Of Application In Conservation. Published by John Wiley and Sons Ltd on behalf of British Ecological Society, Methods in Ecology and Evolution. Vol. 9, p. 20-32, 2018

[36] Williamson, K., Given, L. M., and Scifleet, P. Qualitative data analysis. In Research Methods: Information, Systems, and Contexts: Second Edition. Published by Elsevier Ltd. Australia, 2018

[37] World Bank. The Economic Impact of the 2014 Ebola Epidemic, Online available from Http://Www.Worldbank.Org/En/News/Press-

Release/2014/09/17/Ebola-Economic-Impact-Serious-

Catastrophic-Swift-Response-Countries-International-

Community-World-Bank

[38] Elmahdawy, M., Elsisi, G. H., Carapinha, J., Lamorde, M., Habib, A., Agyie-Baffour, P., ... Usifoh, S., Ebola Virus Epidemic in West Africa: Global Health Economic Challenges, Lessons Learned, and Policy Recommendations. Published by Elsevier Inc, Value in Health Regional Issues. issue 13 C p. 677-, 2017

[39] Koirala, J., and Acharya, S., Impact of Novel Corona Virus (COVID-19 or 2019-nCoV) on Nepalese Economy. SSRN Electronic Journal. March 24, 2020

[40] Shen, G. . Impacts of the COVID-19 Epidemic on China's Trade and Employment and Related Countermeasures. Shanghai University of International Business and Economyc , Journal of Shanghai University of International Business and Economyc, Vol.27, No. 3, p. 16-25, 2020 Reardon, S. F., and Owens, A., 60 Years After Brown: Trends and Consequences of School Segregation. Annual Reviews, A Nonprofit Scientific Publisher, Annual Review of Sociology. Vol. 40, No. 1, :p. 199-218, 2014

[41] Sumarto, M. Welfare Regime Change in Developing Countries: Evidence from Indonesia. John Wiley and Sons, Ltd, Social Policy and Administration. Vol. 51, No. 6, 2017

[42] Wang, C., Cheng, Z., Yue, X.-G., and McAleer, M. (2020). Risk Management of COVID-19 by Universities in China. MDPI Publishing, Journal of Risk and Financial Management. Vol. 13 No. (2), p. 36, 2020

[43] A. Abidah, H.N. Hidayatullah, R.M. simamora, D. Fehabutar, L. Mutakinati, . The Impact of Covid-19 to Indonesian Education and Its Relation to the Philosophy of “ Merdeka Belajar", . Publisher: Indonesia Approach Education, Studies in Philosophy of Science and Education. Vol. 1, No. 1, 2020
[44] Bao, W. COVID-19 and online teaching in higher education: A case study of Peking University. Wiley Periodical LLC, medRxiv, Human Behavior and Emerging Technologies. Vol. 2, p. 113-115, 2020.

[45] Berhe, B., Legese, H., Degefa, H., Adhanom, G., Gebrewahd, A., Mardu, F., ... Negash, H., Global Epidemiology, Pathogenesis, Immune Response, Diagnosis, Treatment, Economic And Psychological Impact, Challenges, And Future Prevention of COVID19: A Scoping Review. MedRxiv. online available from: https://www.medrxiv.org/content/10.1101/2020.04.02.20051052v1.full.pdf

[46] Bruns, D. P., Kraguljac, N. V., and Bruns, T. R. COVID19: Facts, Cultural Considerations, and Risk of Stigmatization. SAGE Publishing, Journal of Transcultural Nursing. Vol. 31(4) 326-332, 2020

[47] Rama, A., and Makhlani, M. Analisis Kesesuaian Konstitusi Ekonomi Indonesia Terhadap Ekonomi Islam. UIN Syarif Hidayatullah Jakarta, Al-Iqtishad: Journal of Islamic Economics, Vol. 6, no. 1, p. 19-41. 2014

[48] Budiyono, B. Hubungan Negara Dan Agama Dalam Negara Pancasila. the Faculty of Law Lampung University, Fiat Justisia. Vol 8, No. 3, p. 410-420, 2015

[49] Flinders. Curriculum Studies Reader E2. Routledge.Taylor and Francis Group, Amerika, 2013

[50] Permendikbud Nomor 69 Tahun 2013. Salinan Lampiran Peraturan Menteri Pendidikan Dan Kebudayaan Nomor 69 Tahun 2013 Tentang Kerangka Dasar Dan Struktur Kurikulum Sekolah Menengah Atas/Madrasah Aliyah Online available from : http://direktori.madrasah.kemenag.go.id ./media/files/Permendikbud69TH2013.pdf

[51] T. Wright, N. Horst, Exploring The Ambiguity What Faculty Leaders Really Think of Sustainability in Higher Education , Emerald Group Publishing Limited, International Journal of Sustainability in Higher Education. Vol. 14. No. 2, pp. 209-227, 2014

[52] Baldo, M. Del.. Corporate Social Responsibility, Entrepreneurial Values and Transcendental Virtues in Italian SMEs. Center for Promoting Ideas, USA, International Journal of Business and Social Science., Vol. 5, No. 6, p. 25-51, 2014. 
Table 4. Basic Competencies of Economics High School (SMA)/MA Curriculum

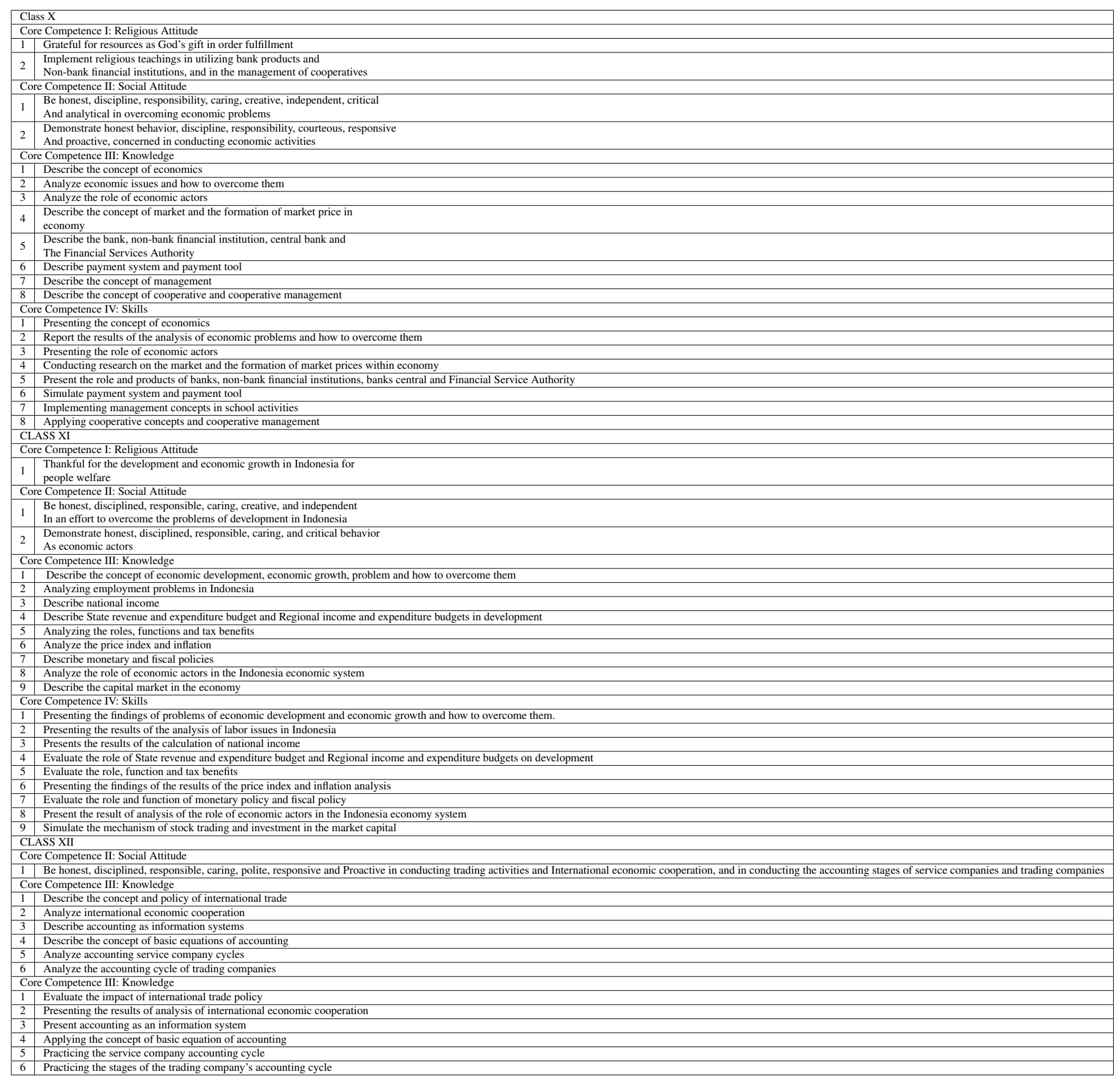

Source: Minister of National Education Regulation, Copy Number 69 of 2013 
Table 5. Course Content of Economics Curriculum 2013 of SMA/MA

\begin{tabular}{|l|l|}
\hline \multicolumn{2}{|l|}{ CLASS X } \\
\hline \multicolumn{1}{|c|}{} & Content \\
\hline 1 & The basic concept of economics \\
\hline 2 & Economic problems \\
\hline 3 & The role of economic actors \\
\hline 4 & The concept of market and the formation of market prices \\
\hline 5 & Banks, non-bank financial institutions, central banks and the Service Authorities Finance (OJK) \\
\hline 6 & Payment systems and payment instruments \\
\hline 7 & The concept of management \\
\hline 8 & Cooperative concepts and cooperative management \\
\hline CLASS XI \\
\hline \multicolumn{1}{|c|}{} & Content \\
\hline 1 & The concept of economic development, economic growth, problems \\
\hline 2 & And how to overcome them \\
\hline 3 & Employment problems in Indonesia \\
\hline 4 & National income \\
\hline 5 & APBN and APBD in development \\
\hline 6 & Roles, functions and tax benefits \\
\hline 7 & Price index and inflation \\
\hline 8 & Monetary and fiscal policy \\
\hline CLASS XII \\
\hline \multicolumn{2}{|l|}{ Content } \\
\hline 1 & International trade policies and concepts \\
\hline 2 & International economic cooperation \\
\hline 3 & Accounting as an information system \\
\hline 4 & The concept of basic equations of accounting \\
\hline 5 & Accounting cycle of service companies \\
\hline 6 & The trading company's accounting cycle \\
\hline
\end{tabular}

